Meta

Journal des tradlucteurs

Translators' Journal

\title{
On the Feasibility and Strategies of Translating Humour
}

\section{Debra S. Raphaelson-West}

Volume 34, numéro 1, mars 1989

Humour et traduction

Humour and Translation

URI : https://id.erudit.org/iderudit/003913ar

DOI : https://doi.org/10.7202/003913ar

Aller au sommaire du numéro

Éditeur(s)

Les Presses de l'Université de Montréal

ISSN

0026-0452 (imprimé)

1492-1421 (numérique)

Découvrir la revue

Citer cet article

Raphaelson-West, D. S. (1989). On the Feasibility and Strategies of Translating Humour. Meta, 34(1), 128-141. https://doi.org/10.7202/003913ar d'utilisation que vous pouvez consulter en ligne.

https://apropos.erudit.org/fr/usagers/politique-dutilisation/ 


\title{
ON THE FEASIBILITY AND STRATEGIES OF TRANSLATING HUMOR
}

\author{
DEBRA S. RAPHAELSON-WEST \\ Georgetown University, Washington, D.C.
}

INTRODUCTION

It is not always possible to translate something such that there is dynamic equivalence. However, there are two kinds of translations to choose from: 1) translation with the goal of dynamic equivalence and 2) translation with the goal of education. It is possible to translate something so that the effects are also translated. If this is impossible, however, it is still possible to do a translation in order to let the reader know that there is something in another language and that it is something like your translation. Using explanation and/or awkward language means sacrificing the dramatic effect, but it is useful for cross-cultural purposes. When translating such intricate pieces as poetry or humor, the second type of translation may be all that can be hoped for.

In The Theory and Practice of Translation, Eugene Nida and Charles Taber have outlined what seems to be a reasonable method of translating from one language to another. They indicate that the "old focus" includes the form of the message, stylistics, rhythm, rhyme, and other rhetorical devices. They imply that this old focus is insufficient: the focus should be on the content. They write: "Anything than can be said in one language can be said in another, unless the form is an essential element of the messagel". Because languages vary, they believe that it is essential to change the form of the message in order to preserve the content of the message.

Using this approach, one may forget important possibilities. The listener or reader is affected by the power of rhetorical devices, not just content. I also believe that although the surface form of a message may change, the extent of this change is a languagespecific question and it is not necessary in all cases to obliterate the original structure.

Nida and Taber have made a number of good points. The translator should preserve meaning as a priority and style as secondary. However, in terms of contexts more literary than the Bible, such as poetry, drama, and humor, the form of the language is an integral part of its original appeal.

In poetry, form is as essential to preserve as content. If the form is not preserved, then neither is the poetry. Susan Bassnett-McGuire writes: "... the degree to which the translator reproduces the form, metre, rhythm, tone, register, etc. of the SL (source language) text, will be as much determined by the TL (target language) system as by the SL system and will also depend on the function of the translation ${ }^{2 "}$. One of the more difficult things to translate is poetry. After many attempts to translate a poem by Anna Akhmatova, and a consolidation of efforts, the final version was proudly presented to a group of translation students, among them speakers of both English and Russian. The final version was judged as having none of the original flavor; the gloss was said to be better than the translation! So there is really no way for a non-native speaker to translate poetry because he cannot feel the effects. Haj Ross puts much effort into describing the precise phonetic construction of poetry. If indeed this is the case, it would be very difficult and rarely worth the effort to produce a translation ${ }^{3}$. 
The way to deal with poetry, then, seems to be the direct translation. That is, produce a gloss of the poem, beside which lies a syllable and rhyme structure to indicate what the original was like.

HUMOR

I have decided to attempt a discussion of the translation of humor. Like poetry, it will often need to be explained and used for instructive purposes. However, in the case of similar cultures and languages, it is often possible to do an effective translation.

By nature, humor is a touchy subject. Among family members around the same dinner table, there will be disagreement about what is funny. A harmless joke could be interpreted as an insult or worse. It is a federal offence (i.e., illegal) for a U.S. citizen to joke about killing the President. In the Soviet Union, there are strict regulations about joking. In an article about Yakov Smirnoff, an American immigrant from the Soviet Union who is now a well-known comedian, Helen Dumar states :

Irreverent humor about official heroes or authority figures is obviously taboo back home. A working comedian submitted material - usually a 10-minute string of gags to what $\mathrm{Mr}$. Smimoff calls the Department of Jokes in the Ministry of Culture and never deviated from the approved subjects. "You're really ending up with mother-in-law jokes, jokes about children, jokes about your drunk neighbor. You can do that as long as you don't say the whole country is drunk"4.

So, for example, such a joke as Smirnoff told to Lawrence Christon of the Los Angeles Times would not be tellable in the USSR: "I think the Russians boycotted the Los Angeles Olympics because of the smog. If anyone tried to defect, you wouldn't be able to see them"5. Emil Draitser discusses the Soviet control of humor:

"Even he who fears nothing, fears laughter," said the great Russian satirist Nikolay Gogol. During the time of Stalin, the careless narrator of a political anecdote could pay, as a result of denunciation, many years of hard labor 6 .

Such control and fear certainly affect the type of humor which becomes widespread.

In the United States, people are permitted and often encouraged to tell whatever type of joke they wish. Even leading Washington politicians (such as Ronald Reagan) will get together for a satirical evening of fun every year (known as the Gridiron). According to Elizabeth Kastor, it is fine and usual for them to make fun of themselves at such an event, but "Out: as always, anything with a sexual over- or under-tone; jokes at the farmers' expense"?. This does not mean, however, that such jokes are not made, only that they are not as well received.

In Washington, D.C. on Martin Luther King Day, a disc jockey known as "The Greaseman" made the comment: "If we kill one black leader and get a day off, why don't we kill four more and get the whole week off?" John Podhoretz writes : "The Greaseman ... whose controversial joke was at best tasteless and at worst despicable, represents the worst face of a certain style of American humor"8. Podhoretz may be right. It may be tasteless and despicable, but not necessarily in the eyes of everyone. (The Greaseman was all but forced to apologize, however.) And perhaps Podhoretz was right about its being American humor, and therefore very difficult to translate without a good explanation. What good explanation can there be for a joke like that?

Even after you have described the point of the joke, there is no guarantee that it will be recognized as humorous. Podhoretz writes : 
The sick joke is, of course, an old and even necessary component of American humor, but this particular brand of it has its roots in a facet of 1960 s drug culture that went largely undiscussed at the time : the psychotic nihilism that went hand in hand with heroin addiction (p. 28).

Telling such a joke, even the above description might not do the trick of convincing the foreigner that murdered black leaders can be humorous.

Oldenburg writes that American men are much more likely to find sexual humor funny that American women (p. B5). Funny jokes may be considered offensive, to American women or to unsuspecting foreigners. Oldenburg also writes about humor in the workplace. He quotes University of Connecticut professor of communications John Parrish Sprowl about humor from the managerial perspective: "We make people less nervous with humor, we make situations more "cope-able" with humor, we make people feel included with humor - most effective managers know how to do that". This is clearly a cultural phenomenon. Humor may be seen as not serious. Georgetown University professor Michael Zarechnak has mentioned the Russian attitude toward humor in a business context: it is ridiculous. It may, therefore, be better to leave a joke untranslated altogether. This is not done, however, according to U.S. State Department translator Dmitry Zarechnak. He says that the joke is usually made because it is important to the speaker. A colleague of his chooses to "warn" the audience that a joke is coming. Unfortunately, after the warning comes the joke, so we may as well think about how to translate it.

Once you have decided to translate humor, the first necessary step of translating a joke would be to analyze the passage. What makes it funny? What type of humor is it? Once you have determined the humor type, you are in a better position to decide whether or not to translate the passage and in a better position to do it properly.

\section{JOKES}

I will begin with jokes, which I have divided into three groups :

1) linguistic, such as puns,

2) cultural, such as ethnic jokes,

3) universal, such as the unexpected.

Going from top to bottom, the jokes are progressively easier to translate. I will demonstrate examples of each.

Linguistic jokes are punny as hell. My previous sentence is a pun, based on the word punny, which rhymes with funny, replacing it in the idiom "funny as hell". It is not hilarious in any language, but its humor is evident in English, and probably only English. In order to translate the joke it would be necessary to have an idiomatic expression about humor which contained a word which rhymed with a word which means something about puns or language. This word which means something linguistic would have to be semotactically similar to the word it rhymes with, and its presence would have to add a little meaning to the sentence. This is very unlikely, and even if it were to happen, the chances of its fitting the context with equal ease of expression are very slim.

Cultural jokes are more widely translatable. For example, if both nations $\mathrm{A}$ and $\mathrm{B}$ had relations with nation $\mathrm{C}$, it would be possible for $\mathrm{A}$ to make jokes about nation $\mathrm{C}$ which could be translated into the language of nation $B$. Translating the joke into language $\mathrm{C}$ might be impossible. Even if the listener is good-natured and can laugh at himself, he might not understand the stereotype. Or, in the case of nation $\mathrm{D}$, they may have no relation to nation $\mathrm{C}$ and will not get the point.

It is difficult to say whether there is such a thing as a "universal joke". Perhaps a universal joke is a bicultural joke. Not being aware of every culture, there is no way for 
me to know whether there are any situations of universal humor. However, there being semantic universals, I venture to say that there are a good number of cultures who would find the following situations funny:

a) a child making extremely mature, adult-like statements

b) a victim getting harmless but embarrassing revenge on his offender

c) the unexpected, unusual response.

Such situations might be offensive to certain people of any culture, but there has been no evidence of whole groups who do not appreciate such events. I do not deny that it is a possibility, but I will call such jokes "universals" for the present time.

\section{LINGUISTIC JOKES}

Linguistic, or language-based jokes are among the most difficult to translate. A major factor is not only the nature of the joke but the relationship of the languages in question. An example is the following Russian joke, from the book Zabavnye Istorii, which is almost impossible to translate into English:

- Mama, a ty vchera prishla iz teatra v pal'to?

- Konechno, moj milyj, a pochemu ty sprashivaesh'?

- A ja slyshal, kak ty skazala babushke, chto papa opyat' posle spektalkja vykinul nomer. ${ }^{9}$

In Russian, the humor comes from the ambiguity: "vykinul nomer" means either "got rid of the claim check" or "kidded around". In English, we see little humor in a literal translation:

- Mom, did you leave the theater last night in your coat?

- Of course, my dear, but why do you ask?

- I heard you tell grandma that Dad was playing tricks again after the show.

The only ambiguity here lies in the complete nonsense of the whole passage. It simply does not translate. If we were to give a translation for purposes other than humor, we could try a different type of translation. The following translation is the sort which says, basically, "This is the basic structure of the humor in the original foreign language. It is obviously a translation, but it is being provided to demonstrate the type of humor which is employed by Russian speakers". Such a joke would serve well to instruct foreigners about certain structures of the language, but it would not serve well in a comedy club.

- Mom, were you wearing your boots when you left the theater?

- Of course, dear. Why do you ask?

- Because I heard you tell grandma that Dad was pulling your leg again after the show.

Here, we have the same type of humor: an idiom which is accidentally (or jokingly) misinterpreted to be the sum of its parts. "Pulling your leg" does not mean "pulling on your leg" but "trying to trick you".

Storozh pojmal mal' chishku, kotoryj voroval jabloki.

-Negodnik! — zakrichal on. - Ja sejchas nauchu tebja kak vorovat'.

-Nu, slava bogu, a to menja uzhe tretij raz lovjat... ${ }^{10}$

Surprisingly enough, however, this one translates perfectly well into English:

The old man caught the little boy stealing apples.

"You no-good thief!" he yelled. "I'll teach you to steal !"

"Thank goodness! This is the third time I've been caught!" 
The irony of the sentence, "I'll teach you to steal", is in the fact that it means exactly the opposite of the surface structure. Clues lie in intonation and context. It is important to realize, therefore, that this joke contains linguistically-oriented humor and that although it translates well into English, it would probably not translate well into other languages.

\section{CULTURAL JOKES}

There are many jokes which may mean the same thing semantically, but in terms of pragmatics and culture, there is something sorely missing which makes the joke untranslatable. Again, it would need to be explicitly a translation for the purposes of cultural education. The following joke would not do very well, probably, in Haiti:

There were paratroopers showing the Californian around their native city of New York. They decided that he could best see it and avoid traffic by jumping out of a plane, so they took him up and all prepared to parachute. They told the Californian, "After you jump, count to ten and then pull the cord". Well, he jumped but fell to the ground before pulling the cord.

When the paratroopers landed, they heard, emitting from beneath a haystack, "six...seven...eight..."

Not knowing about the speaking habits of Californians and New Yorkers, Haitians would not understand this joke. They might surmise that it is funny because if shows the dimwittedness of the Californian, but they would not immediately laugh and say, "That's a good one". To think this is funny, one would have to know that the stereotypical New Yorker speaks very quickly and that the stereotypical Californian speaks relatively slow$1 y$, therefore causing opposing expectations of each other and potential problems for parachute-jumpers.

Many ethnic jokes are interchangeable, however, if a cultural group looks down on another, there need not be such specific references as the parachute joke. All that is necessary is a display of stupidity, and there we have an ethnic joke. These are frequently interchangeable, depending on the audience and the jokester. According to American humorist Larry Wilde, what we call Polish jokes are relatively universal. "In England, they're Irish jokes. In Texas, they're Aggie jokes (about the Texas Agricultural School). In Canada they're Newfie jokes. Here, they're Polish jokes"11. According to Emil Draitser of first the USSR and now UCLA, such jokes Ukrainian jokes to the Russians, who don't joke about the Polish, who are better off in general than theyl2.

Whether it is the Italians or the Polish who are under fire rarely matters in American culture; there is a "stupid joke" for them. The "Jewish American Princess (JAP)" is a spoiled brat. If the listener is unaware of these stereotypes or victimized by the joke, then it would be very difficult to translate it without extensive explanation.

An example of one of the more impossible jokes to translate contains both ethnic and linguistic humor:

"What is the favorite /wain/ of a Jewish American Princess?"

"Ma, can I go to Florida?"

This joke is based on the following assumptions :

1) /wain/ sounds like both wine and whine.

2) Usually, one asks about favorite types of wine, so the whine interpretation is unexpected.

3) It is warm in Florida.

4) People like to vacation where it is warm.

5) Jewish American Princesses are spoiled American girls. 
So when a JAP whines, which is a likely occurrence, the content of her whine often tends to be "Ma, can I go to Florida?" This is a very popular joke in American culture, but it is hard to know offhand whether other English-speaking cultures understand it. Even if the pun were translatable, the listener would have to know not only what a JAP is but where Florida is. The pun is best given in the original so that the pun is visible, and with footnotes explaining its parts. Then, the joke could be instructive about American culture, and might even produce a chuckle.

SATIRE

Satire is difficult to translate because it makes mockery of things that may be sacred to the target culture. There is a chance for effective translation, however, depending on the proximity of the cultures.

It is necessary but perhaps difficult for a non-native speaker to even recognize satire when he sees it. Without a flair for the connotations of a language, the humor may go completely over the head of non-native speakers.

The example I will examine is an essay by Charles Battell Loomis called "Amicus Redivivus"13. Loomis ridicules intellectuals who use quotations in the original foreign tongue and who make esoteric, lofty statements of a fuzzy, philosophical nature. In the end, they seem to be saying nothing. In the United States, whose natives are generally monolingual, to quote a foreign language is considered pretentious. The average reader will not understand such quotations, and will either be irritated or unduly impressed or both.

Loomis has ridiculed by writing an essay which exaggerates the above-mentioned qualities. He does not explicitly denounce such essayists, merely imitates them. A naïve foreigner may easily miss the whole point, assuming that Loomis is merely another philosopher. For a non-American, such quotations may be considered completely appropriate in Europe, whose population is highly educated in languages. Even if the translator is aware that the piece is satirical, he may not find it funny. Once explained to him, he may find it impossible to translate for numerous possible reasons :

1) Such lofty writing does not exist in his society, so there is no basis for ridicule.

2) If such writing exists, it may be appreciated by everyone.

3) The foreign quotations may be understood, while Loomis intended them to be esoteric.

There are possible solutions to these problems. Given a genre of literature which people of the TL consider ridiculous, the "translator" may choose to follow Loomis" lead, not translating the text itself but translating the idea of exaggerating something ridiculous. However, there is a good possibility that exaggeration is only humorous in a cultural context. If the foreign quotations are the only problem, it may hardly be a problem: such quotations could either be left alone, since their content is quite hilarious. It may be an asset to understand them, as long as the general purpose of the essay is understood. It is rare that anything is gained in translation, but this may be one of those cases. For example, Loomis writes: "So, then, may we with an unfaltering trust approach our grave," and, as Schiller says so musically: "Ich kann nicht mit der linken Hand schreiben" 14 . The original target audience, an American one, would probably not understand that German, but the enlightened would chuckle at the idea of quoting German. The enlightened European would know that the German means "I cannot write with my left hand" which is even funnier than the pretentious babble, and makes the joke translate. 
Another rare example of something which is better in the translation is the following Russian joke :

- Prostite, ne mogu li ya videt' mal' chika kur'era? Ya-ego dyadya.

- $O$, Vy ego dyadya? Mne ochen' zhal', no Vy opozdali. On tol'ko chto otprosilsya na Vashi pokhorony ${ }^{15}$.

My English translation is as follows :

"Excuse me, but could I see the messenger boy ? I'm his uncle."

"Oh, you're his uncle? I'm very sorry, but you're late. He has just asked for leave to attend your funeral."

In Russian, the joke is that the boy lied in order to get off work, and was caught in the lie by his uncle's visit. In English, the same joke has added punch by the pun "late". The uncle has not only arrived too late because the boy had left already, but the uncle is "late", another term of "dead".

The joke may not translate into other languages, however, because the attitudes toward lying may differ too much. Ray McDermott, in his discussion of lying, mentions that telling the truth is a culture-dependent activity. Some cultures lie from dawn to dusk (and they sleep in between). Other cultures lie sometimes. You may hear a description, but if your beliefs and actions differ greatly, it will not be appreciated. Another example of belief-dependent joking comes from Humor of America by Max Herzberg and Leon Mones:

To boost the sale of his almanac, Franklin pretended to be an astrologer and prophesized the death of a real astrologer, one Titus Leeds, who obstinately and angrily continued to live though Franklin protested that he was dead and that an imposter was doubling for the deceased Leeds ${ }^{16}$.

The humor here is the irony : making fun of an astrologer while pretending to be an astrologer yourself. For this to be considered funny, not one but two ideas are necessary: 1) astrologer and 2) possibility of no astrologer. So, what is needed is a society which is open to the idea, but open to the possibility that it is not true. If they do not have the idea, they will not know what is happening; if they cannot let go of the idea, they will not think it is funny.

\section{PARODY}

Parody is the mockery of a specific work, and it is among the most difficult things to translate. Besides the cultural and linguistic similarities necessary, the piece of literature being parodied needs to be commonly known in order for the parody to be effective.

Loomis has approached the area of parody as well. Rather than parodying a specific work, he applies one work to the style of three different poets who were well-known in his day. Even the majority of Americans would have a hard time understanding the point of "Jack and Jill as Austin Dobson Might Have Written It"17, or "Jack and Jill as Swinburne Might Have Written It"18. The only way to translate something like that is to take the idea and write a target-culture parody from scratch.

This is what Nabokov skillfully did. Warren Weaver describes many translations of Alice's Adventures in Wonderland, which is rich in humor for both adults and children, including puns, parody, and satire. Weaver refers to a passage from Alice:

Twinkle, Twinkle little bat!

How I wonder what you're at! 
which he says would "to any English child, sound curiously and disturbingly like the familiar couplet :

Twinkle, twinkle little star,

How I wonder what you are!

gone a little queer and wrong" (pp. 81-82).

Vladimir Nabokov wrote his Russian translation in a strange, old dialect. His strategy is excellent: he does not attempt to translate the rhyme but to write a variation of a verse known to Russian children. Weaver writes that Russian children knew a rhyme that went :

Siskin, siskin, where hast thou been?

I have been at the little fountain, drinking vodka.

I drank one little glass,

I drank another little glass,

And it began to buzz in my head.

A version of the original verse :

Chizhik, rizhik, gde ty byl?

Na kanavke vodku pil.

Vypil rjumku, vypil dve,

Zashumelo v golove.

Nabokov wrote a parody of the verse as follows:

Ryzhik' ryzhik, gde ty byl?

Na poljanke dozhdik pil? (p. 62)

Vypil kaplyu, vypil dve.

Stalo syro b golove. (p. 63)

In retranslation, the Russian verse goes something like this :

Mushroom, mushroom, where hast thou been?

On the lawn, drinking the rain.

I drank one drop,

And I drank two drops,

And it became damp in my head. (Weaver, p. 90)

This is as close to dynamic equivalency as it may be possible to come. In both languages, the verses are light children's songs. It is a theoretically sound and highly commendable approach.

Nearly impossible to translate would be something such as was mentioned in the Washington Post by Chuck Conconi: "The [New Republic] cover bears the provocative title: "Springtime for Waldheim", which included a parody of a play called "Springtime for Hitler"19. This is a rhymed parody of a parody of a play, in a film which was popular but hardly a classic. It would take a lot of explaining to get this one through - plus a shared hatred of the Nazi ideals.

\section{GRAMMATICAL ANALYSIS}

It is possible to do without analyzing text, but only for a talented native bilingual. Otherwise, the most intelligent approach will be the analytical one. It is best to begin with the basics. The Nida-Taber treatment of grammatical analysis includes three basic steps for translation : 
1) analysis of the surface structure in terms of (a) grammatical relationships and (b) meanings and combinations of words ;

2) transfer of analyzed material to the target language ;

3) restructuring of the transferred material so that it becomes fully acceptable in the receptor language. ${ }^{20}$

Nida and Taber assert that "grammar has meaning"21. This is true in a very general sense. There are different grammatical constructions which say the same thing, and one grammatical construction can be used to make varied or even opposite assertions. What Nida and Taber suggest is the transformation of the source language (SL) into kernel sentences to be translated into the target language (TL)22. This is an excellent start because it breaks the task up into sub-tasks. Rather than translating a sentence from SL to TL immediately, he rearranges it in the SL, making his next task more comfortable.

It seems as if turning surface structures into kernel sentences is one way of turning the original surface structure into another possible surface structure. Although the final surface structure is easier to deal with, it still contains many of the original problems. For example, on page 35, the problem of of is brought up. In English, $A$ of $B$ can occur whether $A$ is part of $B$ or $B$ is part of $A$ (If Jack is John's son, we may say Jack's John or John's Jack when trying to distinguish from other Jacks or Johns). A of $B$ can occur if $A$ is from $B$ or if $B$ is from $A$ (John of Washington if we are distinguishing Johns, or Washington of John if we are distinguishing DC from Seattle). $A$ of $B$ can occur if $A$ is $B$ like or if $B$ is A-like (the word of truth or the truth of the word). These two phrases have different meanings, but may be expressed the same way.

The kernel sentence analysis will change these phrases to The word is true and The truth which is apparent by the word. It is an essential transformation. A generative semantics model may be preferable, however, because of the nonlinear orientation of morphemes instead of strings of grammatical sentences. As Cook points out, generative semantics (GS) was developed by Lakoff, McCawley, Ross, et al., "because deep structure does not go deep enough"23. GS is an attempt to draw a direct connection between the surface structure and the meaning. It is an attempt at a universal semantic theory based on the notion that the verb is central. It is around the verb that the rest is based; the grammar of a sentence is based on the valence of the verb, which is based on the meaning in context (not necessarily the literal meaning, but the intended use).

Rather that a linear representation, which would differ from language to language, semantics is represented on a tree structure, which is not present in any conventional representation of language. Although trees of kernel sentences may be drawn, GS is unique in that the tree is the only form. The final sentence is usually derived in order to test the theory, but I would like to propose that the tree be formulated from the SL and the sentence be derived using rules of the TL.

By using tree structures instead of grammatical sentences, the structure is made apparent. By using morphemes (parts of words) instead of (whole) words, the translator is less likely to think in terms of grammatical source language but to think in terms of the meaning of the sentence. Taking the semantic relations instead of grammatical relations, he will be able to start with the meaning and work to the language rather than having to transform one surface structure to another. This is sure to leave some prints from the SL on the TL translation and give it an unnatural SL flavor.

I would like to use an example from Lewis Carroll's Alice in Wonderland. A class of Russian students at Georgetown University were asked to translate the first paragraph into Russian : 
Alice was beginning to get very tired of sitting by her sister on the bank, and of having nothing to do. Once or twice she had peeped into the book her sister was reading, but it had no pictures or conversations in it. "And what is the use of a book," thought Alice, "without pictures or conversations?"

First we were asked to translate it into kernel sentences, and everyone came up with something like the following:

1. Alice began to get tired (of something).

2. Alice sat by her sister on the bank.

3. Alice had nothing to do.

4. Alice peeped into the book.

5. Her sister read a book.

6. The book had no conversations (etc.)

Problems can be encountered from the first kernel. They do not look problematic, and this is the source of one problem : the translations may be incorrect without the translator's realizing that there had even been a difficulty. Professional translators, as is expected, have no trouble with this. Nabokov's translation of "tired of" was stanovilos' skuchno 24 which means basically the same thing, "became bored". A 1977 translation by A. Scherakov reads "utomitel "no", which is "tired of". The simplicity of word-for-word translation is an easy trap to fall into, however, as demonstrated by the Russian class. A majority of the class transformed Alice was beginning to get very tired of... as the Russian sentence Alisa nachinala ustavat'... In actuality, they transformed get very tired of into get very tired (from). It is very likely that Alice was not tired but restless (quite the opposite!).

The problem was predictable, however. Translating from one linear structure to another makes it tempting to translate too literally. After discussing the true meaning, the Russian Alisa nachinala nadoedat' became the more accepted translation. While the kernel sentence reads Alice was beginning to get tired of (something), the logical structure of the sentence makes it easier to see what is going on. So, rather than using the kernel sentence as it is, translating the format into a tree makes the relationships more apparent. One is forced to decide whether the word of is part of the prepositional phrase or whether it is part of the verb, whereas with the kernel sentence, it lies exactly between both and no decisions need be made. The logical structure appears as follows, for the sentence "Alice was beginning to get tired of sitting on the bank next to her sister and of having nothing to do": 


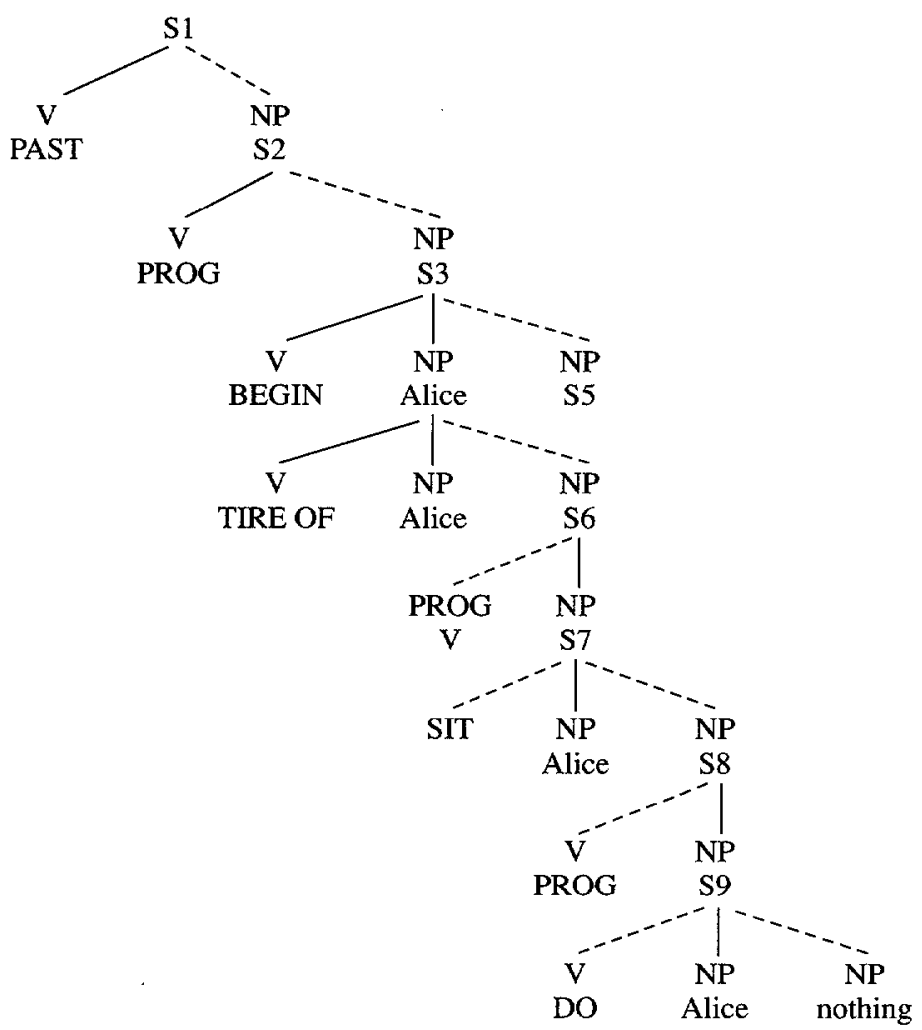

The above structure makes it clear that Alice is beginning to get tired of something. The kernel sentence, even in the form of a tree, would not so clearly illustrate the relationships or so cleanly isolate the verb from the rest of the sentence. Rather than keeping a grammatical word order, generative semantics focuses on the central element, the verb, and places it at the beginning of the sentence, forcing the translator to decide whether the accompanying prepositions are an intrinsic part of the verb.

The linear form of the sentence may be formed only by "derivation rules", which are language-specific rules. The source-language surface can be transformed into a logical morpheme structure and rules of the target language may be used to derive an appropriate translation.

Fillmore points out that "... when both the verbal and the nominal use of a word refer to events of the same type, the event-description should, other things being equal, appear only once in the lexicon"25. He is not specifically referring to generative semantics, but his words indicate that he would agree with its philosophy. In GS, two sentences which mean the same thing are assigned the same logical structure regardless of surface structure, whether the similarity lies in the morphology of a noun-verb or the synonymity of two verbs. For example, $\mathrm{He}$ is inconsiderate and He is not considerate have the same logical structure. He made Mary sing and He caused Mary to sing have the same logical structure. Of course, such simple cases are few and far between, but the fact that they exist at all indicates the economical, meaning-preserving nature of generative semantics and its de-emphasis on the surface structure. 
Nida and Taber suggest five steps for the analysis:

1) identify basic structural elements

2) make the implicit statements explicit

3) determine the basic kernels of the surface structure

4) relate the kernels to each other

5) state the relationships in a form which is optimal for transfer into the receptor language 26 .

A translator ought to, as Nida and Taber suggest as step 5, relate the form which is optimal for transfer into the receptor language. They discuss the relations between two kernels, which may be (1) temporal, (2) spatial, and (3) logical. In terms of formatting these relations for transfer, a basic tree structure of the morphology is ideal. If the target language lacks these morphemes, they may to be constructed by combining available morphemes. If the lexical and/or semantic gaps are too common, perhaps a translation for persuasive purposes is not worth the effort.

Semanticist Victor Raskin has taken up the study of jokes and what makes them funny. "The text is a joke if it is compatible, fully or in part, with two distinct scripts, and the two scripts are opposite in certain definite ways." For example, Raskin provides the following joke:

"Is the doctor in?" the patient asked in his bronchial whisper.

"No," the doctor's young and pretty wife whispered in reply. "Come right in."

The joke illustrates an overlap of two distinct scripts, DOCTOR and LOVER (or ADULTERY)... The two scripts must also be opposite in a special sense. Usually, this opposition is between actual and not actual: One script refers to the real, normal or possible situation as reflected in the text and the other to an unreal, abnormal or impossible situation. ${ }^{27}$

It seems feasible to combine Raskin's approach with that of generative semantics. In order to insure the transference of humor, it might be useful to have a couple of branches on the tree to indicate what the contrastive scripts are. For example, for a pun, there would be a twig to balance out the word:

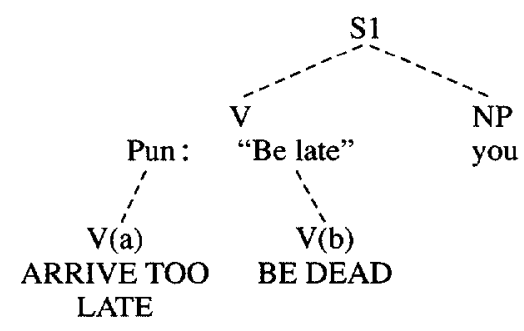

For a parody, on the other hand, it would be necessary to have an extra branch.

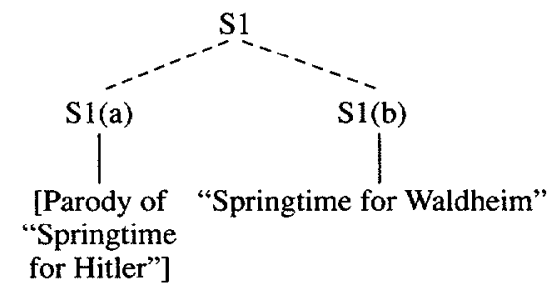


Even if there is no translation for the pun, this will alert the translator to the need to invent a pun - or perhaps eliminate the joke. It depends on the context.

Max Herzberg and Leon Mones seem to have hit upon the real issue: jokes are translatable if and only if the respective cultures are interested and available. "To be ready for the appreciation and enjoyment of humor, one must be ready to play. For the essence of the sense of humor is the readiness to play." They also say that humor is "an enjoyable juggling with social taboos, with this or that forbidden action or custom. It is playing with illusions until truth is illuminated as never before"28.

The real question is "Who wants to see the truth?"

It is possible to translate humor if you keep in mind that the translation will not always be as humorous as the original. What is essential is to keep the cultural context in mind, to locate the humorous aspect or aspects of the text, and to try to explain or duplicate these aspects. It has been suggested that one way of doing this is through semantic trees, creating branches which account for the humor and the dual scripts. If the dual script is amusing in one language but not in the target language, it may be easier to write a new, target-culture based joke instead of trying to translate the original.

Notes

1. Eugene A. Nida and Charles R. Taber (1982): The Theory and Practice of Translation, vol. III of Helps for Translators, Leiden, E.J. Brill, p. 4.

2. Susan Bassnett-McGuire (1980) : Translation Studies, London, Methuen, Inc., p. 80.

3. Haj Ross (1985): "Structural Prosody", to appear in Haj Ross, The Language of Poetry.

4. Helen Dumar (1984): "From Russia with Laugh", in The Wall Street Journal, East Edition, August 20, p. 13.

5. Lawrence Christon (1984): “Jakov Smirnoff: The Comrade Knows Funny", in The Los Angeles Times, August 2, Sec. C, p. 79.

6. Emil Draitser (1978): Nedozvolennyj Smekh (Forbidden Laughter), Los Angeles, Almanac Publishing (translated by Jon Pariser).

7. Elizabeth Kastor (1986): "Signs \& Arrows", in The Washington Post, March 24, p. C11.

8. John Podhoretz (1985) : "Critic At Large", The Washington Times, March 5.

9. L.F. Kuzemchenko (1982) : Zabavnye Istorii, Moscow, Russkij Jazyk, p. 18.

10. Ibid.

11. Larry Wilde, personal communication, March 29, 1986, WHMM Conference, Arizona State University.

12. Emil Draitser (1986): "How Russian Humor Differs from American Humor", March 29, WHIM Conference, Arizona State University.

13. Charles Battell Loomis (1901): The Four-Masted Cat Boat and Other Truthful Tales, Freeport, NY, Books for Libraries Press, pp. 231-235.

14. Ibid., p. 235.

15. Kuzemchenko, p. 21.

16. Max J. Herzberg and Leon Mones (1945): Humor of America, New York, D. Appleton-Century Company, Incorporated, p. 11.

17. Charles Battell Loomis (1899) : Just Rhymes, New York, R.H. Russell, p. 64.

18. Ibid. (1899): p. 66 .

19. Chuck Conconi (1986): "Personalities", The Washington Post, March 24, p. C4.

20. Nida and Taber, p. 33.

21. Nida and Taber, p. 35

22. Nida and Taber, p. 39.

23. Walter A. Cook (1985): Generative Semantics, unpublished notes, Washington, DC, Georgetown University, pp. v-vii.

24. Lewis Carroll (1976) : Anya V Stranye Chudes, New York, Dover Publications, translated from the English by Vladimir Nabokov, p. 5 .

25. Charles Fillmore (1971): "Types of Lexical Information", in Danny D. Steinberg and Leon A. Jakobovits (eds.), Semantics, Cambridge, Cambridge University Press, p. 385.

26. Nida and Taber, p. 51.

27. Victor Raskin (1985) : "Jokes", Psychotogy Today, October, p. 36.

28. Herzberg and Mones, p. 3. 


\section{BIBLIOGRAPHY}

BASSNETT-McGUIRE, Susan (1980) : Translation Studies, London, Methuen, Inc.

CARROLL, Lewis (1976): Anya V Stranye Chudes, New York, Dover Publications, translated from the English by Vladimir Nabokov.

CHRISTON, Lawrence (1984): "Jakov Smirnoff: The Comrade Knows Funny", The Los Angeles Times, August 12, Sec. C, p. 79.

CONCONI, Chuck (1986) : "Personalities", The Washington Post, March 24, p. C3.

COOK, Walter A. (1985) : Generative Semantics, unpublished notes, Washinton, DC, Georgetown University.

DRAITSER, Emil (1978) : Nedozvolennyj Smekh, (Forbidden Laughter), Los Angeles, Almanac Publishing, translated by Jon Pariser.

DRAITSER, Emil (1986): "How Russian Humor Differs from American Humor", Lecture at WHIM Conference, Arizona State University, March 29.

DUMAR, Helen (1984) : "From Russia with Laugh", The Wall Street Journal, East Edition, August 20, p. 13.

FILLMORE, Charles (1971): "Types of Lexical Information", in Danny D. Steinberg and Leon A. Jakobovits (eds.), Semantics, Cambridge, Cambridge University Press, pp. 370-392.

JEERBERG, Max J. and Leon MONES (1945): Humor of America, New York, D. Appleton-Century Company, Incorporated.

KASTOR, Elizabeth (1986) : "Signs \& Arrows", The Washington Post, March 24, pp. C1, C11.

KUZEMCHENKO, L.F. (1982) : Zabavnye Istorii, Moscow, Russkij Jazyk.

LOOMIS, Charles Battell (1899): Just Rhymes, New York, R.H. Russell.

LOOMIS, Charles Battell (1901): The Four-Masted Cat Boat and Other Truthful Tales, Freeport, NY, Books for Libraries Press.

McDERMOTT, Ray (1986) : Telling the Truth, public lecture, Georgetown University.

NIDA, Eugene A. and Charles R. TABER (1982): The Theory and Practice of Translation, vol. III of Helps for Translators, Leiden, E.J. Brill.

OLDENBURG, Don (1986) : "The Bottom Line is Laughter", The Washington Post, March 4, p. B5.

PODHORETZ, John (1985): "Critic at Large", The Washington Times, March 5, pp. 28-38.

RASKIN, Victor (1985) : "Jokes", Psychology Today, October, pp. 34-39.

ROSS, Haj (1985) : "Structural Prosody", to appear in Haj Ross, The Language of Poetry, MTT, 1986.

WEAVER, Warren (1964): Alice in Many Tongues: The Translations of Alice in Wonderland, Madison, The University of Wisconsin Press.

ZARECHNAK, Dmitry (1986) : Lecture in "Linguistics and Translation", March 20, Georgetown Universiy. 